\title{
MENINGKATKAN OPTIMISME REMAJA PANTI SOSIAL DENGAN PELATIHAN BERPIKIR POSITIF
}

\section{INCREASING OPTIMISM OF SOCIAL INSTITUTION ADOLESCENT WITH POSITIVE THINKING TRAINING}

\author{
Mutya Nurindah \\ Fakultas Psikologi dan IImu Sosial Budaya Universitas Islam Indonesia Yogyakarta \\ E-mail: ct_venska@yahoo.com \\ Tina Afiatin \\ Fakultas Psikologi Universitas Gadjah Mada \\ Indahria Sulistyarini \\ Fakultas Psikologi dan Ilmu Sosial Budaya Universitas Islam Indonesia Yogyakarta
}

\begin{abstract}
This study was aimed to examine if there was effects of thinking positively for enhancing optimism on teenagers living in social institution. The subjects of this study were male and female teenagers who live in a social institution no less than one year, aged 13 to 18 years old, and have at least junior high academic background. The datas were collected using optimism device made by researcher based on McGinnis theory (1995) which consists of 28 items, interviews, and observations. The observer of thinking positively practice used to thinking positively practice manual arranged by the researcher based on cognitive approach technique. The comparison of the optimism score increase in on pre test, post test, and follow up along with the interview datas showed that there was an optimism between subjects who received thinking positively training and those who did not receive. The subjects who received the training had an increased of the optimism score.
\end{abstract}

Key words: thinking positively training, optimism, living-in-social-institution teenagers 


\section{ABSTRAK}

Penelitian ini bertujuan untuk menguji apakah ada pengaruh pelatihan berpikir positif terhadap optimisme pada remaja yang tinggal di panti sosial. Hipotesis penelitian ini adalah ada perbedaan optimisme antara remaja yang mendapat pelatihan berpikir positif dan yang tidak mendapatkan pelatihan berpikir positif. Subjek dalam penelitian ini adalah 20 remaja putra dan putri yang minimal 1 tahun tinggal di panti, berusia 13 sampai 18 tahun, dan tingkat pendidikan minimal SLTP. Pengumpulan data dilakukan dengan menggunakan alat tes optimisme yang dibuat oleh peneliti berdasarkan teori McGinnis (1995), wawancara dan observasi. Pelaksanaan pelatihan berpikir positif mengacu pada manual pelatihan berpikir positif yang telah disusun oleh peneliti dengan mengacu pada teknik pendekatan kognitif. Hasil evaluasi perbandingan skor optimisme saat prates, pascates dan tindak lanjut serta data hasil wawancara dan observasi menunjukkan bahwa ada perbedaan peningkatan optimisme antara subjek yang mendapat pelatihan berpikir positif dan yang tidak mendapat pelatihan berpikir positif. Subjek yang mengikuti pelatihan berpikir positif mengalami peningkatan skor optimisme.

Kata kunci: pelatihan berpikir positif, optimisme, remaja panti sosial

Anak-anak terlantar adalah para terarah guna menjamin pertumbuhan korban permasalahan sosial yang dan perkembangan anak baik fisik, perlu mendapatkan perhatian khusus. mental, spritual, maupun sosial. Hal Anak-anak tersebut adalah generasi ini dimaksudkan untuk mewujudkan penerus yang oleh berbagai sebab harus kehidupan terbaik bagi anak yang diharapkan menerima kenyataan pahit untuk hidup terlantar tanpa terpenuhinya kebutuhan dasar mereka secara layak. Permasalahan mengenai anak terlantar muncul sebagai akibat dari adanya kegagalan pemenuhan kebutuhan dasar anak-anak atau kurangnya perhatian dan pengawasan terhadap kesehatan dan keamanan anak-anak.

Undang-undang Nomor 23Tahun 2002 berisi mengenai pertanggungjawaban orang tua, keluarga, masyarakat, pemerintah, dan negara merupakan rangkaian kegiatan yang dilaksanakan secara terus menerus demi terlindunginya hak-hak anak. Rangkaian kegiatan tersebut harus berkesinambungan dan sebagai penerus bangsa yang potensial, tangguh, dan memiliki nasionalisme yang dijiwai oleh akhlak mulia (http:// yanrehsos.depsos.go.id, 3/8/2009).

Kenyataannya, tidak semua anak memperoleh hak dan kesempatan yang sama serta tidak setiap anak terlindungi dalam satu keutuhan keluarga yang dapat memenuhi kebutuhan emosional dan fisik secara optimal. Ada kondisi tertentu yang menyebabkan seseorang berada di lembaga yang bernama panti asuhan. Masalah yang mereka alami di antaranya adalah adanya kasus perdagangan anak, anak terlantar, anak jalanan, anak yatim, anak piatu, anak yatim piatu, anak 
nakal, pekerja anak, permasalahan anak akibat kecacatan, dan jenis permasalahan anak karena kondisi ekonomi misalnya pengemis dan gelandangan (http:// yanrehsos. depsos.go.id, 3/8/2009).

Menurut BPKKS (Badan Pembinaan Kegiatan Kesejahteraan Sosial), panti asuhan adalah sebuah lembaga untuk mengasuh, menjaga, dan memberikan bimbingan pada anak dengan tujuan agar mereka menjadi manusia dewasa yang cakap dan berguna serta bertanggung jawab atas dirinya dan terhadap masyarakat di kemudian hari (Napitupulu, Nashori, \& Kurniawan, 2007). Panti sosial disebut juga dengan panti asuhan yang merupakan tempat penampungan bagi anak-anak terlantar dan bertujuan untuk memenuhi kebutuhan anak asuhnya baik dari segi fisik maupun psikis (Peraturan Pemerintah Republik Indonesia Nomor 129 Tahun 2000). Panti asuhan memiliki peran sebagai pengganti keluarga dalam memenuhi kebutuhan anak dalam proses perkembangannya dan tidak hanya sebagai tempat penitipan, tapi juga menjadi sarana penggodokan mental agar kelak mereka mampu berdiri sendiri.

Seiring dengan pertambahan usianya, seorang remaja akan dihadapkan pada tugas perkembangan baru. Tak jarang mereka menemui berbagai permasalahan yang dapat berubah menjadi kesulitan jika tidak segera diatasi. Khusus untuk remaja panti asuhan, mereka memiliki tambahan permasalahan berkaitan dengan konsep diri yang negatif. Ciri konsep diri yang negatif adalah peka terhadap kritik, responsif terhadap pujian, memiliki sikap hiperkritis, cenderung merasa tidak disukai orang lain, dan kurang optimis terhadap kompetisi (Ghufron \& Risnawita, 2010).

Lukman (2000) menjelaskan, konsep diri negatif tersebut muncul berkaitan dengan keberadaan anak panti asuhan yang melabel dirinya sebagai anak yang perlu dikasihani. Label yang muncul secara internal dan juga didukung pandangan sosial menjadikan mereka bimbang dalam menilai diri mereka sendiri. Label anak panti juga dapat menyebabkan anak asuh menjadi pribadi yang kurang mandiri, takut dalam melakukan aktivitas yang menyangkut diri sendiri dan selalu membutuhkan bantuan dari orang lain.

Hasil penelitian Fabrykowski dan Piver (2008) menunjukkan bahwa karakteristik anak panti asuhan meliputi menyalahkan diri sendiri, merasa tidak berdaya yang merupakan salah satu ciri rendahnya optimisme, merasa kehilangan dan dikhianati, memiliki stigma sebagai anak yang ditelantarkan dan sifat rusak, disosiasi, gangguan kepribadian ganda, serta gangguan kelekatan. Karakteristik yang dimiliki anak panti asuhan tersebut disebabkan oleh adanya trauma dan penelantaran oleh keluarga mereka. 
Sejumlah penulis (Hanafi, Kurniawan, Dodik, Kusumayudha, Tehupeiory, \& Arifin, 2010) menunjukkan bahwa sebagian dari anak-anak yang tinggal di Panti Sosial Asuhan Anak " $X$ " memiliki optimisme yang rendah, di antaranya menganggap diri mereka sebagai orang yang tidak mampu untuk memecahkan masalah dan merasa tidak mempunyai masa depan yang lebih baik. Faktor-faktor yang memengaruhi rendahnya optimisme anak panti antara lain disebabkan hampir seluruh anak panti berasal dari keluarga yang kurang mampu dan bermasalah, kultur budaya yang kurang baik dan kurangnya pendamping yang bertugas mendampingi atau mengasuh mereka, sehingga membuat anak-anak panti merasa kurang mendapat perhatian.

Setiap orang dapat dikatakan pernah mengalami suatu persoalan atau permasalahan yang sulit dan kadangkadang tidak terpecahkan. Saat mengatasi masalah, setiap orang mempunyai cara yang berbeda-beda. Ada yang menghadapinya dengan cara kurang optimis dan ada pula yang menghadapinya dengan sangat optimis. Orang yang mempunyai pandangan optimis dalam menghadapi masalah akan mempunyai cara yang berbeda. la cenderung percaya bahwa kegagalan adalah suatu hal yang temporer dan hanya terjadi pada kasus tersebut. Sejumlah penulis (Raikkonen, Matthews, Flory, Owens, \& Gump, 1999) menjelaskan bahwa orang yang kurang optimis lebih berusaha untuk menarik diri, menjadi pasif, dan mudah menyerah dalam mencapai tujuannya. Rendahnya optimisme disebabkan adanya keyakinan negatif terhadap diri yang didasari oleh cara berpikir yang salah.

Hasil penelitian Napitupulu, Nashori, dan Kurniawan (2007) menunjukkan bahwa anak panti asuhan memiliki keinginan dasar untuk dapat diterima apa adanya oleh lingkungan, menjadi yang terbaik, dan berhasil dalam hidupnya, untuk mewujudkan semua itu akan ada hambatan dan kesulitan yang muncul. Salah satu sumber kesulitan tersebut dapat muncul dari pola pikir yang keliru misalnya tinggal di panti asuhan berarti hidup dengan keterbatasan-keterbatasan.

Barualogo (2004) lebih lanjut menjelaskan dari hasil penelitiannya bahwa sebagian anak panti asuhan menerima pendapat negatif dari lingkungan mengenai anak panti asuhan dan meyakini kebenaran pendapat tersebut. Hal ini menimbulkan optimisme yang rendah, rasa tidak percaya diri pada anak sehingga merasa terasing, tidak disayangi, tidak mampu mengekspresikan atau mempertahankan diri dan tidak mampu mengatasi kelemahan mereka.

Peterson (2000) mengungkapkan bahwa adanya bermacam-macam keuntungan dari optimisme. Seiring dengan hal itu ditemukan pula kekurangan dari optimisme yang rendah. Optimisme berkaitan dengan perasaan positif, keuntungan dari 
optimisme berdampak pada moral yang baik, ketekunan, pemecahan masalah yang efektif, akademik, atletik, militer, pekerjaan, kesuksesan politik, popularitas, kesehatan yang lebih baik, bahkan untuk memperpanjang umur dan bebas dari stres serta trauma. Sebaliknya, optimisme yang rendah merupakan pertanda munculnya depresi, pasif, kegagalan, kerenggangan sosial, serta menimbulkan kemungkinan munculnya penyakit dan kematian.

Snyder dan Lopez (2002) menyatakan bahwa individu yang memiliki optimisme rendah mengalami distorsi kognitif di dalam pikirannya. Pikiran-pikiran yang tidak realistis, menyebabkan perasaan negatif, disboria, cemas dan membuat individu berhenti untuk mencoba berusaha mencapai tujuan mereka. Kognitif dan pernyataan diri yang negatif membuat individu merasa tidak mampu memecahkan masalah yang dihadapi. Tujuan dari terapi kognitif adalah mengubah kognisinya yang negatif menjadi positif.

Peterson (2000) dalam penelitiannya menjelaskan bahwa seseorang yang optimis terhadap masa depannya dipengaruhi oleh berpikir positif. Berdasarkan hasil penelitian yang telah dilakukan oleh Rachmahana (1996) didapatkan bahwa dengan berpikir positif, individu mampu melihat kejadian yang tidak mengenakkan secara lebih objektif, tidak langsung menyalahkan diri sendiri, dan mampu mengenali kemampuan-kemampuan yang ada pada dirinya sehingga pola pikirnya yang semula negatif menjadi lebih realistis.

Peale (2008) menjelaskan bahwa individu yang berpikir positif akan memberikan dampak pada kesuksesan, menghasilkan optimisme, memiliki kemampuan pemecahan masalah dan menjauhkan diri dari perasaan takut akan kegagalan. la juga akan melihat pada kekuatan diri dengan dasar pemikiran bahwa setiap orang sama berartinya dengan orang lain. Di samping itu, ia akan menyesuaikan diri dengan kenyataan, menjauhkan diri dari penyesalan, frustrasi, dan hal-hal lain yang dapat menimbulkan perasaan tidak menyenangkan. Secara psikologis seseorang yang mempunyai cara berpikir positif akan merasakan ketenangan, penuh optimisme, penuh penerimaan, mempunyai harga diri yang baik, dapat mengambil hikmah dari suatu kejadian tanpa selalu menyalahkan halhal di luar dirinya. Sebaliknya, mereka yang mempunyai cara berpikir negatif akan selalu merasa cemas, tegang, kurang optimis dalam menghadapi hidup sehingga jiwanya tidak merasa tenang dan tidak dapat mengambil makna dari suatu pengalaman.

Berdasarkan hasil penelitian sejumlah penulis (Wadsworth, Gudmundsen, Raviv, Ahlkvist, Mclntosh, Kline, Rea, \& Burwell, 2004) diketahui bahwa berpikir positif merupakan strategi merefleksikan usaha yang dilakukan oleh seseorang untuk 
menyesuaikan diri dengan lingkungan yang dinilai penuh tekanan. Berpikir positif dapat juga diartikan sebagai usaha yang dilakukan oleh seseorang dalam melihat segala sesuatu tidak hanya sebatas pada kegagalan dan berpikir positif ini menjadi sarana untuk dapat mengatasi berbagai pikiran negatif. Hal ini juga akan memengaruhi bagaimana seseorang memandang dirinya sendiri dan bagaimana memandang permasalahan yang dihadapinya (Albrecht, 1980).

Remaja yang mempunyai optimisme akan mampu bertahan dalam menghadapi masalah dengan tetap mempunyai keyakinan bahwa dirinya akan berhasil. Karakteristik dari optimisme mempunyai dampak penting pada cara individu merespon kesulitan. Remaja yang kurang optimis akan mengantisipasi kegagalan sebagai sebuah musibah yang akan berlangsung lama dalam hidupnya, selalu terjadi di setiap aspek hidupnya dan kegagalan tersebut disebabkan oleh kesalahannya sendiri (Lopez \& Snyder, 2002).

Alasan mengapa penelitian ini masih perlu dilakukan lagi karena belum adanya penelitian terdahulu yang melibatkan sisi positif atau potensi-potensi yang dimiliki individu di antaranya yaitu berpikir positif untuk meningkatkan optimisme pada remaja panti sosial. Penelitian ini bertujuan untuk membuktikan efektifitas pelatihan berpikir positif sebagai sarana untuk mengubah cara berpikir yang negatif sehingga dapat meningkatkan optimisme pada remaja panti sosial, maka perlu dilakukan penelitian ini.

Berpikir positif merupakan suatu keterampilan kognitif yang dapat dipelajari melalui pelatihan, individu yang kurang optimis melalui pelatihan berpikir positif akan mengalami proses pembelajaran ketrampilan kognitif dalam memandang berbagai peristiwa yang dialami (Lestari \& Lestari, 2005). Pelatihan berpikir positif memfokuskan pada aspek-aspek positif dari keadaan diri individu, orang lain maupun lingkungan serta masalah yang dihadapi. Pelatihan berpikir positif juga berkaitan dengan perhatian positif dan perkataan atau ungkapan-ungkapan positif (Albrecht, 1980).

Pelatihan ini merupakan salah satu bentuk intervensi dengan menggunakan pendekatan kognitif. Pendekatan kognitif merupakan pendekatan untuk menangani depresi, yang menyatakan secara tegas bahwa depresi adalah gangguan kognitif yang karakteristiknya berupa pandangan yang negatif mengenai diri sendiri, pengalaman dan masa depannya yang disebabkan oleh optimisme yang rendah dan keputusasaan (Peterson, 2000).

Berdasarkan apa yang telah dikemukakan di atas, maka diketahui bahwa salah satu hal yang memengaruhi rendahnya optimisme remaja di panti sosial yaitu cara berpikir yang negatif karena adanya pengaruh kondisi keluarga dan label sebagai anak panti asuhan, sehingga untuk 
mengubah kondisi tersebut diperlukan cara berpikir yang berbeda. Penelitian ini ingin membuktikan bahwa pelatihan berpikir positif dapat meningkatkan optimisme remaja di panti sosial berkaitan dengan permasalahan yang mereka alami.

Optimisme merupakan harapan dan cara seseorang memandang masa depan serta konsekuensi dari cara pandang tersebut (positif atau negatif) terhadap keberhasilan dan kegagalan, yang membentuk perilakunya sekarang (menyangkut tingkat usaha yang dilakukan untuk mencapai tujuan masa depan). Manifestasi dari hal tersebut adalah menyangkut penilaian terhadap hasil perilakunya, disebabkan oleh faktor internal atau eksternal.

McGinnis (1995) mengemukakan aspek-aspek optimisme adalah: (a) Mempunyai pengendalian atas perasaan negatifnya; (b) Menganggap dirinya sebagai orang yang mampu untuk memecahkan masalah; (c) Merasa mempunyai pengendalian atas masa depan; (d) Selalu gembira bahkan ketika tidak bisa merasa bahagia; (e) Menerima apa yang tidak dapat diubah. Faktor-faktor yang memengaruhi optimisme pada remaja panti sosial adalah faktor eksternal berupa lingkungan dan faktor internal yaitu dari dalam diri sendiri atau personal. Faktor lingkungan melingkupi rumah atau panti, guru atau pengasuh dan keluarga, sedangkan faktor dari dalam diri sendiri yaitu kepercayaan diri baik pada kekuatan pada diri sendiri maupun pada Tuhan, harga diri, dan refleksi diri.

Berpikir positif diartikan sebagai cara berpikir yang lebih memusatkan pada keadaan diri, orang lain, maupun lingkungan serta masalah yang dihadapi meliputi perhatian dan perkataan positif. Albrecht (1980) mengatakan bahwa dalam berpikir positif terdapat aspek-aspek sebagai berikut: (a) Harapan yang positif, dalam hal ini ketika menyampaikan sesuatu lebih dipusatkan pada hal yang positif; (b) Afirmasi diri, yaitu memusatkan perhatian pada kekuatan diri, melihat diri secara positif; (c) Pernyataan yang tidak menilai (non judgement thinking), yaitu suatu pernyataan yang lebih menggambarkan keadaan; (d) Penyesuaian diri yang realistik (realistic adaptation), mengakui kenyataan dan segera berusaha menyesuaikan diri dari penyesalan, frustrasi, dan menyalahkan diri sendiri.

Pelatihan berpikir positif memfokuskan pada keadaan diri individu, orang lain maupun lingkungan serta masalah yang dihadapi. Pelatihan berpikir positif juga berkaitan dengan perhatian positif dan perkataan atau ungkapan-ungkapan positif. Pelatihan ini diarahkan pada berpikir positif untuk meningkatkan optimisme pada remaja di panti sosial. Metode yang diberikan berupa psikoedukasi, self awareness, penghapusan distorsi kognitif (mengenal jenis distorsi kognitif, melawan pikiran 
negatif), pengembangan kemampuan melihat sisi positif (harapan baru, adaptasi terhadap kenyataan), penguatan (teknik afirmasi diri atau verbalisasi yang positif) serta latihan (Susetyo, 2006).

Kartono (1990) mengatakan bahwa masa remaja juga sebagai masa penghubung atau masa peralihan antara masa kanak-kanak dengan masa dewasa. Pada masa remaja terjadi perubahan-perubahan besar dan esensial mengenai fungsi-fungsi rohaniah dan jasmaniah. Perubahan yang sangat menonjol pada periode ini adalah kesadaran yang mendalam mengenai diri sendiri di mana remaja mulai meyakini kemampuan, potensi, dan cita-cita sendiri. Kesadaran tersebut membuat remaja berusaha menemukan jalan hidupnya dan mulai mencari nilai-nilai tertentu, seperti kebaikan, keluhuran, kebijaksanaan, dan keindahan. Simanjuntak (1990) menguraikan ciri-ciri remaja yaitu: (a) Perubahan fisik; (b) Perubahan sosial; (c) Perkembangan psikososial; (d) Persahabatan; (e) Emosi; (f) Hubungan dengan orangtua.

Individu yang tinggal di panti asuhan atau sosial adalah mereka yang memiliki kasus perdagangan anak, anak terlantar, anak jalanan, anak yatim, anak piatu, anak yatim piatu, anak nakal, pekerja anak, permasalahan anak akibat kecacatan dan jenis permasalahan anak karena kondisi ekonomi, misalnya pengemis dan gelandangan. Individu yang tinggal di panti asuhan berasal dari latar belakang yang berbeda serta usia yang berbeda-beda pula, namun kebanyakan dari mereka masih berusia anak-anak dan remaja awal. Mereka oleh pihak panti asuhan dididik dan dibina, selain diberikan layananlayanan yang mereka butuhkan.

Pihak panti asuhan membantu membimbing anak asuhan untuk bekerja sama, disiplin diri ke arah kebiasaan, toleransi serta tanggung jawab terhadap berbagai tugas keluarga, bantuan khusus dalam hal bimbingan belajar, menciptakan suasana yang menguntungkan bagi terciptanya proses pengembangan kemampuan dan ketrampilan tertentu. Adanya suasana pengertian, perhatian, dan kasih sayang akan membantu perkembangan anak (Sumhudi, 1995).

Penelitian ini bertujuan untuk mengetahui pengaruh pelatihan berpikir positif untuk meningkatkan optimisme bagi remaja panti sosial. Hipotesis yang diajukan adalah ada perbedaan tingkat optimisme pada remaja panti sosial sebelum diberi perlakuan pelatihan berpikir positif dan sesudah diberi pelatihan berpikir positif. Setelah diberi pelatihan berpikir positif, tingkat optimisme pada kelompok eksperimen lebih tinggi daripada kelompok kontrol. 


\section{METODE PENELITIAN}

\section{Subjek Penelitian}

Subjek penelitian diperoleh dengan melakukan screening atau penyebaran skala optimisme kepada remaja panti sosial asuhan anak " $\mathrm{X}$ " untuk mencari subjek yang memiliki skor optimisme diri sedang dan rendah berdasarkan mean hipotetik. Kemudian subjek dipilih secara random (random assignment) yang mempunyai makna bahwa subjek mempunyai probabilitas yang sama untuk memperoleh kesempatan menjadi subjek penelitian, serta guna mengontrol ancaman internal dan menghindari ancaman seleksi dalam eksperimen. Subjek yang dipilih secara random dibagi menjadi dua kelompok yaitu kelompok kontrol dan kelompok eksperimen.

Subjek penelitian ini adalah remaja tengah yang berusia 15 sampai 18 tahun dengan tingkat pendidikan minimal SLTP. Subjek tinggal minimal selama setahun di panti sosial asuhan anak " $\mathrm{X}$ ", berjenis kelamin laki-laki dan perempuan.

Subjek penelitian berjumlah 20 orang, jumlah kelompok eksperimen dan kelompok kontrol masing-masing berjumlah 10 orang. Subjek tinggal selama 1 sampai 7 tahun di panti sosial asuhan anak " $X$ ", berjenis kelamin laki-laki dan perempuan dengan tingkat pendidikan SMP dan SMA. Subjek kelompok eksperimen berusia 14 sampai 17 tahun, sedangkan subjek kelompok kontrol berusia 13 sampai 18 tahun.

\section{Rancangan Penelitian}

Rancangan penelitian yang digunakan adalah rancangan kelompok kontrol prates-pascates (pretest-posttest control group design). Prates dilakukan sebelum pelatihan untuk melihat kondisi awal peserta diukur tingkat optimismenya dengan menggunakan skala optimisme remaja panti sosial. Pascates dilakukan setelah pelatihan berakhir, masih menggunakan skala yang sama sebagai evaluasi hasil pelatihan. Dua minggu setelah semua sesi pelatihan berakhir, dilakukan pengukuran skala optimisme sebagai tindak lanjut (follow up) untuk melihat efektivitas pelatihan lebih lanjut.

\section{Metode Pengumpulan Data}

Pengumpulan data dalam penelitian ini diperoleh melalui kuesioner yang berbentuk skala. Skala yang digunakan dalam penelitian ini adalah skala optimisme dari McGinnis (1995) yang disusun sendiri oleh peneliti yang terdiri atas beberapa aspek yaitu: mempunyai pengendalian atas perasaan negatifnya, menganggap dirinya sebagai orang yang mampu untuk memecahkan masalah, merasa mempunyai pengendalian atas masa depan, selalu gembira bahkan ketika tidak bisa merasa bahagia, menerima apa yang tidak dapat diubah. Pola dasar pengukuran skala optimisme ini mengikuti metode skala Likert. Pilihan jawaban memiliki empat alternatif yaitu Sangat Sesuai (SS), Sesuai (S), Tidak Sesuai (TS), dan Sangat Tidak Sesuai (STS). 
Setelah menyusun aitem skala optiminsme, peneliti melakukan uji coba Skala Optimisme. Uji coba dilakukan untuk menentukan validitas dan reliabilitas Skala Optimisme. Uji coba dilakukan pada tanggal 22 Maret 2011 dan diberikan kepada 50 remaja di panti asuhan "Y", Yogyakarta. Hasil analisis aitem Skala Optimisme menunjukkan bahwa dari sebanyak 50 butir aitem awal, diperoleh 28 aitem sahih dan 22 aitem gugur. Nilai korelasi aitem bergerak antara 0,263 sampai 0,676 . Pertimbangan yang dipakai adalah jika nilai korelasi aitem di atas 0,25 , maka suatu aitem dinyatakan sahih. Jika nilai korelasi aitem di bawah 0,25, maka aitem tersebut dinyatakan gugur. Realibilitas Skala Optimisme dalam penelitian ini dianalisis dengan menggunakan formula Alpha Cronbach melalui program SPSS 18 release for windows. Pengujian dilakukan tiga kali putaran terhadap seluruh aitem yang sahih, sehingga didapatkan koefisien reliabilitas skala sebesar 0,863 .

\section{Prosedur Perlakuan}

Penelitian ini dilakukan dalam beberapa tahap, yaitu:

1. Persiapan penelitian yang meliputi:

a. Melakukan studi pendahuluan terhadap seluruh remaja di panti sosial asuhan anak " $X$ ", Yogyakarta. Remaja yang dijadikan subjek diberi informed consent untuk kesediaannya mengikuti pelatihan. b. Menyusun dan menguji coba skala optimisme. Peneliti melakukan seleksi partisipan untuk menentukan partisipan yang akan terlibat dalam pelatihan dengan berpedoman pada kri-teria partisipan penelitian yang telah ditentukan sebelumnya. Screening untuk optimisme berjumlah 50 soal. Screening yang digunakan untuk optimisme ini dibuat sendiri oleh peneliti berdasarkan teori McGinnis (1995). Hasil uji coba sudah diterangkan dalam subbagian Metode Pengumpulan Data.

c. Uji coba modul pelatihan. Uji coba dilakukan untuk mengetahui apakah prosedur pelatihan yang meliputi durasi waktu pada masingmasing sesi serta materi dapat dipahami oleh peserta. Uji coba modul dilakukan pada tanggal 24, 25, 26, dan 27 Maret 2011 dengan menggunakan teknik role play dan diberikan kepada remaja panti asuhan "Y" di Yogyakarta sebanyak 5 orang yang terdiri dari 3 orang perempuan dan 2 orang laki-laki. Dari hasil uji coba diketahui bahwa perlunya penambahan waktu untuk setiap sesi sekitar 10 menit, sedangkan untuk materi sudah dapat dipakai karena mudah untuk dipahami.

d. Mengurus perijinan untuk melakukan penelitian. Sebelum penelitian dilak- 
sanakan, terlebih dahulu peneliti melakukan persiapan-persiapan yang berkaitan dengan administrasi penelitian, yaitu masalah perijinan. Prosedur perizinan ini dimulai dengan surat pengantar izin penelitian dari pihak Program Magister Profesi Psikologi Universitas Islam Indonesia pada tanggal 25 Februari 2011, kemudian surat tersebut diserahkan kepada Biro Administrasi Pembangunan yang berada di Kompleks Kepatihan, Danurejan, Yogyakarta. Setelah surat pengantar dari Biro Administrasi Pembangunan dibuat, surat selanjutnya diberikan pada Dinas Sosial Provinsi Daerah Istimewa Yogyakarta untuk diproses kemudian tanggal 28 Februari 2011 surat izin penelitian dari Dinas Sosial diserahkan pada Panti Sosial Asuhan Anak "X", Yogyakarta.

h. Observasi dalam penelitian ini dilakukan tiap pertemuan. Pencatatan data dilakukan secara kualitatif dengan mencatat sebanyak-banyaknya data yang mendukung suatu gejala tanpa disertai interpretasi atau evaluasi dari observer.

2. Pelaksanaan penelitian yang meliputi:

a. Subjek kelompok eksperimen dan kelompok kontrol yang dilibatkan dalam penelitian, diberikan informed consent dan surat kesediaan menjadi subjek dalam penelitian ini. b. Prates diberikan kepada subjek penelitian sebelum pelatihan diberikan, sedangkan untuk pascates diberikan kepada subjek penelitian setelah proses pelatihan selesai.

c. Pelatihan berpikir positif dilaksanakan sebanyak empat kali pertemuan. Pada setiap minggu dilaksanakan dua pertemuan, sehingga total waktu yang diperlukan dalam melaksanakan program ini selama dua minggu. Masing-masing pertemuan dilakukan sekitar 100 menit. Setelah 4 kali pelatihan berpikir positif selesai dilakukan, partisipan diberikan lembar evaluasi pelatihan dan langsung dilakukan pascates dengan memberikan skala optimisme. Hal ini dilakukan untuk melihat efektivitas pemberian pelatihan berpikir positif terhadap optimisme remaja di panti sosial.

d. Tahap akhir berupa pelaksanaan tindak lanjut (follow up) yang dilakukan dua minggu setelah pelaksanaan pascates. Pelaksanaan tindak lanjut dilakukan dengan memberikan skala optimisme kepada partisipan dan melakukan wawancara individual. Wawancara individual bertujuan untuk melihat sejauhmana pengaruh pelatihan pada diri masing-masing partisipan dan penerapannya dalam kehidupan sehari-hari. 


\section{Metode Analisis Data}

Analisis data yang digunakan dalam penelitian ini adalah analisis kuantitatif dan kualitatif. Analisis data kuantitatif yang digunakan adalah uji $\mathrm{t}$ dengan menggunakan data gained score yang merupakan skor selisih antara hasil prates, pascates dan tindak lanjut (follow up). Analisis data menggunakan SPSS 18 release for windows. Penelitian ini menggunakan uji $\mathrm{t}$ untuk analisis data kuantitatif karena uji t merupakan prosedur pengujian parametrik rata-rata dua kelompok data, baik untuk kelompok data terkait maupun dua kelompok bebas. Untuk jumlah data yang sedikit maka perlu dilakukan uji normalitas dan uji homogenitas.

Analisis data kualitatif dilakukan secara individual dengan bertujuan untuk menjelaskan proses-proses berpikir positif yang terjadi pada masing-masing individu. Proses analisis data secara kualitatif dilakukan dengan analisis deskriptif dengan mengolah data yang diperoleh dari observasi selama pelatihan dan wawancara yang dilakukan kepada peserta eksperimen saat tindak lanjut (follow up).

\section{HASIL PENELITIAN}

\section{Hasil Analisis Kuantitatif}

Pengukuran dalam penelitian ini dilakukan sebanyak tiga kali, yaitu sebelum pelatihan dilaksanakan (prates), setelah pelatihan dilaksanakan (pascates), dan sekitar dua minggu setelah pelatihan dilaksanakan (follow-up). 
Tabel 1. Skor optimisme kelompok eksperimen-kelompok kontrol pada prates, pascates, tindak lanjut, dan gained score

\begin{tabular}{|c|c|c|c|c|c|c|c|}
\hline \multirow{3}{*}{ Kelompok } & \multirow{3}{*}{ Subjek } & \multirow{3}{*}{$\begin{array}{c}\text { Jenis } \\
\text { Kelamin }\end{array}$} & \multicolumn{5}{|c|}{ Pengukuran } \\
\hline & & & Prator & Daccates & Tindak & Gained & Gained \\
\hline & & & Prates & rascates & lanjut & Score 1 & Score 2 \\
\hline \multirow{10}{*}{ Eksperimen } & S1/RS & Laki-laki & 84 & 88 & 99 & 4 & 15 \\
\hline & $\mathrm{S} 2 / \mathrm{R}$ & Perempuan & 77 & 84 & 88 & 7 & 11 \\
\hline & $\mathrm{S} 3 / \mathrm{T}$ & Laki-laki & 83 & 85 & 90 & 2 & 7 \\
\hline & $\mathrm{S} 4 / \mathrm{K}$ & Laki-laki & 78 & 84 & 91 & 6 & 13 \\
\hline & S5/SP & Perempuan & 74 & 84 & 89 & 10 & 15 \\
\hline & S6/ES & Laki-laki & 72 & 87 & 95 & 15 & 23 \\
\hline & $S 7 / Y$ & Perempuan & 72 & 84 & 96 & 12 & 24 \\
\hline & S8/NA & Perempuan & 71 & 88 & 96 & 17 & 25 \\
\hline & S9/TA & Perempuan & 69 & 84 & 90 & 15 & 21 \\
\hline & S10/J & Perempuan & 66 & 84 & 93 & 18 & 27 \\
\hline \multicolumn{3}{|c|}{ Mean $=$ Total/ $\mathrm{N}$} & 74,6 & 85,2 & 92,7 & 10,6 & 18,1 \\
\hline \multirow{10}{*}{ Kontrol } & S1/YA & Laki-laki & 74 & 83 & 77 & 9 & 3 \\
\hline & $\mathrm{S} 2 / \mathrm{N}$ & Laki-laki & 75 & 79 & 74 & 4 & -1 \\
\hline & $\mathrm{S} 3 / \mathrm{MN}$ & Laki-laki & 74 & 77 & 72 & 3 & -2 \\
\hline & S4/PA & Laki-laki & 82 & 81 & 80 & -1 & -2 \\
\hline & S5/NW & Perempuan & 66 & 78 & 77 & 12 & 11 \\
\hline & S6/RK & Perempuan & 80 & 83 & 79 & 3 & -1 \\
\hline & S7/UF & Perempuan & 71 & 77 & 75 & 6 & 4 \\
\hline & S8/AF & Perempuan & 79 & 83 & 75 & 4 & -4 \\
\hline & S9/UR & Perempuan & 69 & 67 & 70 & -2 & 1 \\
\hline & S10/PP & Perempuan & 80 & 79 & 73 & -1 & -7 \\
\hline \multicolumn{3}{|c|}{ Mean $=$ Total $/ \mathrm{N}$} & 75 & 78,7 & 75,2 & 3,7 & 0,2 \\
\hline
\end{tabular}

\section{Keterangan:}

Gain Score 1: Pascates-prates

Gain Score 2: Tindak lanjut-prates 
Adapun deskripsi data penelitian tersaji pada tabel 2 di bawah ini:

Tabel 2. Statistik deskriptif kelompok eksperimen dan kontrol

\begin{tabular}{lccccc}
\hline \multicolumn{1}{c}{ Kelompok } & N & Minimum & Maximum & Mean & $\begin{array}{c}\text { Standar } \\
\text { Deviasi }\end{array}$ \\
\hline Prates eksperimen & 10 & 66,00 & 84,00 & 74,6000 & 5,85377 \\
Pascates eksperimen & 10 & 84,00 & 88,00 & 85,2000 & 1,75119 \\
Tindak lanjut eksperimen & 10 & 88,00 & 99,00 & 92,7000 & 3,65300 \\
Prates kontrol & 10 & 66,00 & 82,00 & 75,0000 & 5,27046 \\
Pascates kontrol & 10 & 67,00 & 83,00 & 78,7000 & 4,76212 \\
Tindak lanjut kontrol & 10 & 70,00 & 80,00 & 75,2000 & 3,11983 \\
Valid N (listwise) & 10 & & & & \\
\hline
\end{tabular}

\section{Hasil Uji Asumsi}

Sebelum melakukan analisis statistik lebih jauh, peneliti melakukan uji normalitas untuk mengetahui apakah sebaran distribusi data tergolong normal atau tidak. Uji normalitas sebaran dilakukan dengan menggunakan One Sample Kolmogorov-Smirnov Test. Kaidah yang digunakan untuk mengetahui normalitas sebaran data adalah jika $\mathrm{p}>$ 0,05 maka dikatakan sebaran normal. Jika $\mathrm{p}<0,05$, maka sebaran tidak normal. Hasil uji normalitas dari skala optimisme diperoleh nilai K-SZ $=0,659$ dan nilai $\mathrm{p}$ $=0,779$ berarti nilai $p>0.05$, sehingga dikatakan normal.

Selanjutnya peneliti melakukan uji homogenitas untuk menentukan apakah frekuensi/varians antara kedua kelompok sebelum perlakuan yang diujikan tersebut tidak berbeda secara signifikan. Kaidah uji yang digunakan jika $\mathrm{p}>0,05$ maka varians dapat dikatakan homogen, dan
Jika $\mathrm{p}<0,05$ maka variannya tidak homogen. Uji homogen dilakukan dengan menggunakan teknik Homogenity-of variance One-Way ANOVA program SPSS 18 release for windows. Hasil uji homogenitas pada skala optimisme memperoleh nilai Levene Statistic = 1,567 dan nilai $p=0,227$ berarti nilai $p$ $>0,05$, sehingga dikatakan homogen.

\section{Hasil Uji Hipotesis}

Hipotesis dalam penelitian ini adalah ada perbedaan tingkat optimisme pada remaja panti sosial sebelum diberi perlakuan pelatihan berpikir positif dan sesudah diberi pelatihan berpikir positif. Setelah diberi pelatihan berpikir positif terjadi perbedaan peningkatan tingkat optimisme pada kelompok eksperimen lebih tinggi daripada kelompok kontrol. Pengujian hipotesis dilakukan dengan uji t gained score, hasilnya dapat dilihat dalam tabel berikut ini: 
Tabel 3. Hasil uji t gained score optimisme antara kelompok eksperimen dan kelompok kontrol

\begin{tabular}{lccc}
\hline \multicolumn{1}{c}{ Pengukuran } & T & P & Keterangan \\
\hline Prates-Pascates & 3,024 & 0,007 & Signifikan \\
Prates-Tindak lanjut & 6,742 & 0,000 & Signifikan \\
\hline
\end{tabular}

Pada tabel di atas menunjukkan data dari gained score bahwa pada prates dan pascates skala optimisme ada perbedaan optimisme antara kelompok eksperimen dengan kelompok kontrol dengan nilai $\mathrm{t}$ $=3,024$ dan nilai $\mathrm{p}=0,007$, berarti nilai $p<0,05$. Sedangkan dari gained score pada prates dan tindak lanjut (follow up) skala optimisme menunjukkan ada perbedaan optimisme antara kelompok eksperimen dengan kelompok kontrol dengan nilai $\mathrm{t}=6,742$ dan nilai $\mathrm{p}=$ 0,000 , berarti nilai $p<0,05$.

\section{Hasil Analisis Kualitatif}

Berdasarkan hasil kategori laporan analisis kualitatif pada penelitian ini dapat diketahui bahwa sebelum mengikuti pelatihan berpikir positif, sebagian besar remaja yang tinggal di panti sosial " $X$ " merasa kurang percaya diri atau rendah diri, kurang optimis, tertutup, bergantung pada orang lain jika ada masalah, dan merasa kurang tenang. Setelah mengikuti pelatihan berpikir positif, remaja yang tinggal di panti sosial tersebut mampu memahami pola pikir negatif, dapat melawan pola pikir negatif, dapat menggunakan pola pikir positif untuk menghadapi peristiwa kehidupan yang akan datang, optimisme meningkat, ada motivasi untuk menghadapi masa depan, memiliki tujuan hidup, mampu dalam menghadapi masalah secara mandiri, percaya diri, merasa tenang, dan terbuka.

\section{PEMBAHASAN}

Permasalahan utama yang menjadi fokus penelitian ini adalah untuk mengetahui bahwa pelatihan berpikir positif mampu untuk meningkatkan optimisme bagi remaja panti sosial "X". Berdasarkan hasil analisis data diketahui bahwa terdapat perbedaan optimisme antara kelompok eksperimen yang mengikuti pelatihan berpikir positif dengan kelompok kontrol yang tidak mengikuti pelatihan. Kelompok eksperimen yang telah diberi pelatihan berpikir positif mengalami peningkatan optimisme daripada kelompok kontrol yang tidak mengikuti pelatihan berpikir positif.

Peneliti melakukan analisis data yang didapat dari prates terhadap kelompok eksperimen dan kelompok kontrol. Hasilnya diketahui bahwa kelompok eksperimen dan kelompok kontrol berada dalam kondisi yang sama, artinya memiliki pemahaman yang sama mengenai optimisme. Penyamaan kondisi ini adalah usaha untuk meminimalisasi 
ancaman terhadap validitas internal. Bila semua subjek memiliki kemampuan yang sama, maka akan memudahkan peserta untuk menerima materi pelatihan dan memiliki peluang untuk bisa meningkat lagi ketika diberikan pelatihan (Bowling, 2002).

Data statistik kelompok eksperimen menunjukkan rerata pre tes 74,600 , pada pascates adalah 85,200 dan pada tindak lanjut (follow up) adalah 92,700. Hal ini menunjukkan bahwa ada peningkatan optimisme setelah mengikuti pelatihan berpikir positif. Sedangkan rerata pada kelompok kontrol saat prates adalah 75,000, pada pascates yaitu 78,700 namun ada penurunan pada saat tindak lanjut (follow up) yaitu menjadi 75,200.

Berdasarkan hasil analisis uji $\mathrm{t}$ dengan gained score menunjukkan bahwa ada perbedaan skor optimisme pada saat sebelum (prates) dan sesudah pelatihan (pascates). Uji $\mathrm{t}$ dengan gained score skala optimisme kelompok eksperimen dan kelompok kontrol diketahui ada perubahan optimisme yang signifikan antara kelompok eksperimen dan kelompok kontrol.

Hal ini ditunjukkan oleh nilai $\mathrm{t}=$ 3,024 dan nilai $p=0,007$, berarti nilai $p<0,05$, yang artinya ada perbedaan optimisme yang signifikan setelah mengikuti pelatihan berpikir positif. Hal ini berlaku juga pada prates dan tindak lanjut (follow up) yaitu $\mathrm{t}=6,742$ dan nilai $\mathrm{p}=$ 0,000 , hal ini berarti $p<0,05$. Menurut hasil penelitian yang dilakukan oleh Pawitra dan Chan (2003), peningkatan ini terjadi dari tahap perkembangan belajar, yaitu pada tahap pertama (saya tahu), kedua (saya mengerti) dan ketiga (saya bisa).

Data statistik menunjukkan bahwa ada perbedaan optimisme yang signifikan antara kelompok kontrol dan kelompok eksperimen pada saat tindak lanjut (follow up), sehingga dapat dijelaskan bahwa apa yang diperoleh oleh kelompok eksperimen dalam pelatihan masih terus diterapkan hingga waktu kurang lebih dua minggu setelah pelatihan. Peserta yang telah mendapatkan pengetahuan mengenai berpikir positif merasa tertarik dengan hasil yang akan didapatkan bila mereka menerapkan dan mengembangkan keterampilan berpikir positif.

Berdasarkan hasil observasi diketahui bahwa pada saat awal pelatihan beberapa peserta tampak lebih banyak diam dan tidak banyak mengemukakan pendapat. Setelah mengikuti pelatihan beberapa sesi, para peserta terlihat mulai aktif, cukup banyak mengemukakan pendapat, kooperatif, serta terbuka tentang pengalaman dan perasaan yang dialami selama latihan.

Metode refleksi yang melibatkan peserta membuat peserta percaya diri untuk mengungkapkan pendapatnya. Setelah mendapat pelatihan, optimisme kelompok yang mendapat perlakuan, menjadi meningkat. Hal tersebut dilihat 
dari perbedaan skor yang diperoleh antara kelompok yang diberi pelatihan dan yang tidak diberi pelatihan. Kelompok yang tidak diberi pelatihan tidak mengalami peningkatan optimisme. Peningkatan optimisme antar peserta pada kelompok yang mendapat pelatihan tergolong dalam kategori tinggi, disebabkan oleh kemampuan peserta dalam menyerap materi pelatihan dan proses belajar yang digunakan oleh para peserta.

Suatu penelitian yang berbentuk eksperimen, tidak terlepas dari halhal yang mengancam validitas internal penelitian. Peneliti berusaha untuk meminimalisasi ancaman tersebut dengan cara memberikan prates kepada kedua kelompok penelitian, sehingga setiap peserta diketahui memiliki pengetahuan yang sama. Peneliti juga meminimalisasi ancaman kebosanan yang terjadi selama penelitian berlangsung, yaitu memberikan hiburan ketika peserta terlihat lelah dan bosan, juga menyediakan konsumsi agar peserta tidak merasa lapar. Untuk meminimalisasi regresi statistik, peneliti melakukan random assignment, tidak mengambil subjek pada keadaan yang paling ekstrem tetapi membagi sama rata kemampuan subjek ke dalam dua kelompok.

Keterbatasan dalam penelitian ini adalah: (1) generalisasi hasil penelitian terbatas pada subjek yang mengalami skor optimisme pada remaja dalam kategori sedang saja sehingga belum diketahui efeknya pada optimisme dengan kategori rendah dan sangat rendah; (2) subjek dalam penelitian ini terbatas pada remaja yang tinggal di PSAA " $X$ " saja dan belum diketahui efeknya pada remaja lainnya; (3) belum tersedianya informed consent bagi observer dan fasilitator.

\section{PENUTUP}

\section{Simpulan}

Hasil penelitian menunjukkan bahwa pelatihan berpikir positif dapat meningkatkan optimisme pada remaja yang tinggal di panti sosial. Selain meningkatkan optimisme, latihan berpikir positif juga dapat memberikan motivasi untuk menghadapi masa depan, memiliki tujuan hidup, mampu memahami pola pikir negatif, dapat melawan pola pikir negatif, lebih berpikir positif dalam menghadapi segala sesuatu, memiliki kemampuan dalam menghadapi masalah, merasa tenang, terbuka, dan percaya diri. Manfaat pelatihan berpikir positif akan lebih optimal sejauh pelaksanaannya tetap dilaksanakan secara rutin dalam kehidupan sehari-hari.

\section{Saran}

Berdasarkan pengalaman dan pertimbangan, peneliti menyampaikan beberapa saran sebagai berikut:

1. Para peneliti dalam bidang sejenis

a. Para peneliti selanjutnya diharapkan dapat memperhatikan keterbatasan generalisasi dalam penelitian ini, sehingga dapat melakukan 
penelitian dengan jangkauan generalisasi yang lebih luas, seperti meneliti remaja di panti-panti yang lain.

b. Peneliti selanjutnya dapat melihat efektivitas pelatihan ini tidak hanya dari tingkat optimisme pada remaja, namun dapat juga mengukur mengenai tingkat penerimaan diri atau kepercayaan diri untuk mendapatkan data yang semakin lengkap.

\section{Subjek penelitian}

Remaja perlu memperhatikan agar pengetahuan dan pemahaman yang telah diperoleh dari pelatihan berpikir positif ini dapat diterapkan ke dalam perilaku maupun cara berpikir sehari-hari. Jika hal ini dilakukan, maka permasalahan yang terkait dengan optimisme yang rendah dapat ditangani secara dini. Bila memungkinkan dapat memberikan bantuan dan masukan kepada temantemannya yang mengalami optimisme rendah dengan teknik dan cara-cara yang telah bersama-sama dipelajari.

3. Pihak panti

Modul pelatihan berpikir positif ini dapat direkomendasikan kepada psikolog yang bekerja di panti " $\mathrm{X}$ " agar memberikan program berupa pelatihan berpikir positif kepada para remaja mengenai bahasan pengenalan berpikir positif, manfaat berpikir positif, serta cara mengelola pikiran positif sehingga dapat meningkatkan optimisme remaja yang tinggal di panti. Psikolog panti juga dapat memberikan training pada pengasuh panti berupa pemberian psikoedukasi berpikir positif, sehingga pengasuh mampu menerapkannya pada remaja yang tinggal di panti sosial " $X$ ".

\section{DAFTAR PUSTAKA}

Albrecht, K. (1980). Brain Power: Learn to Improve Your Thinking Skills. New York: Rinehart and Winston.

Azwar, S. (2007). Penyusunan Skala Psikologi. Yogyakarta: Pustaka Pelajar.

Barualogo, I. S. (2004). Hubungan Antara Persepsi Tentang Figur Attachment Dengan Self-Esteem Remaja Panti Asuhan Muhammadiyah. Jurnal Psikologi, 13, 29-49.

Bowling, A. (2002). Research Methods in Health: Investigating Health and Health Services (ed. Ke-2). Buckingham Philadelphia: Open University Press.

Fabrykowski, K. N., \& Piver, P. S. (2008). Caring for Foster Children in the South. Why They Did Not Have Even One Person to Care for Them. Journal of Education, 129, 192-200.

Ghufron, M. N., \& Risnawita, R. (2010). Teori-teori Psikologi. Yogyakarta: ArRuzz Media. 
Hanafi, M., Kurniawan, T. V., Dodik, A. A., Kusumayudha, J. S., Tehupeiory, V. Y., \& Arifin, D. (2010). Laporan Pelaksanaan Praktik Psikologi Terapan. Yogyakarta: Fakultas Psikologi Universitas Mercu Buana.

Kartono, K. (1990). Psikologi Anak. Bandung: Mandar Maju.

Lestari, R., \& Lestari, S. (2005). Pelatihan Berpikir Optimis Untuk Mengubah Perilaku Coping Pada Mahasiswa. Jurnal Psikodinamik, 7, 1-10.

Lukman, M. (2000). Kemandirian Anak Asuh Di Panti Asuhan Yatim Islam Ditinjau Dari Konsep Diri Dan Kompetensi Interpersonal. Jurnal Psikologika, 5, 57- 74.

McGinnis, A. L. (1995). Kekuatan Optimisme (Adiwiyoto, A, Penerj). Jakarta: Mitra Utama.

Napitupulu, L., Nashori, H. F., \& Kurniawan, I. N. (2007). Pelatihan Adversity Intelligence Untuk Meningkatkan Kebermaknaan Hidup Remaja Panti Asuhan. Jurnal Psikologika, 13, 43-56.

Panti Sosial Asuhan Anak Tunas Bangsa Pati, Jawa Tengah. Diunduh pada 3 Agustus 2009, dari http:// yanrehsos.depsos.go.id/modules. php name $=$ News \&file $=$ article $\& s$ $\mathrm{id}=362$.
Pawitra, T., \& Chan, K. C. (2003). From Action Learning to the Teaching Organization: An Experiential Approach. Gadjah Mada International Journal of Business, 5, 131-144.

Peale, N. V. (2008). Berpikir Positif Untuk Remaja (Utomo, T. W, Penerj). Yogyakarta: Baca.

Peraturan Pemerintah Republik Indonesia Nomor 129. (2000). Himpunan Peraturan Perundang-undangan Republik Indonesia Reformasi-2000 (Jilid IV). Jakarta: CV. Citra Mandiri.

Peterson, C. (2000). The Future of Optimism. American Psychologist, 55, 44-55.

Rachmahana, R. S. (1996). Efektivitas Training "Positive Thinking" dalam Meningkatkan Harga Diri Mahasiswa. Jurnal Logika, 3, 18-27.

Raikkonen, K., Matthews, K. A., Flory, J. D., Owens, J. F., \& Gump, B. B. (1999). Effects of Optimism, Pesimism, and Trait Anxiety on Ambulatory Blood Pressure and Mood During Everyday Life. Journal of Personality and Social Psychology, 76, 104-113.

Simanjuntak, B. (1990). Pengantar Psikologi Perkembangan. Bandung: Tarsito 
Snyder, C. R., \& Lopez, S. J. (2002). Wadsworth, M. E. Gudmundsen, G. R., Handbook of Positive Psychology. Raviv., T., Ahlkvist, J. A., Mclntosh, New York: Oxford University Press. $\quad$ D. N., Kline, G., Rea, J., \& Burwell,

Sumhudi. (1995). Kesejahteraan Anak R. A. (2004). Coping With Terrorism:

Dan Keluarga. Jakarta: Direktorat Jenderal Rehabilitasi Dan Pelayanan Sosial. Age and Gender Differences in Effortful and Involuntary Responses to September $11^{\text {th }}$. Journal of Applied And Developmental Science, 8,

Susetyo, Y. F. (2006). Pengembangan 143-157.

Perilaku Mengajar Yang Humanis Guru Sekolah Dasar Setelah Menjalani Pelatihan Berpikir Positif. Jurnal Penelitian BAPPEDA Kota Yogyakarta, 1, 28-35. 